\title{
Technological-level evaluation using patent statistics: model and application in mobile communications
}

\author{
Ilgu Cho • Myeongcheol Park
}

Received: 14 November 2013 / Revised: 28 January 2014 / Accepted: 4 March 2014 / Published online: 25 March 2014

(C) The Author(s) 2014. This article is published with open access at Springerlink.com

\begin{abstract}
Information and communication technology (ICT) has been a driving force of development for knowledgebased economies. In particular, as competition in mobile communications technological innovation among nations becomes more intense, there are growing demands for improved evaluation, judgment, and prediction of mobile communications technological capability in order to improve national ICT competitiveness. Technological capability refers to conceptual-level elements that capture technological competitiveness in operation. A technological level can be defined for making comparisons of one technological capability with another. Patent statistics have been used by economists and researchers in the field of innovation to analyze current and forecast technological directions. This paper evaluates relative technological capability in terms of patent statistics for some technology domains. We propose a patent statistic model for relative technological capability based on patent activity, intensity, market-power, and citation index for mobile communications technologies at a national level. In particular, it gives a technological-level evaluation of 3G, $3 \mathrm{G}$ transitional, and $4 \mathrm{G}$ mobile communications for the US, EU, Japan, China, and Korea.
\end{abstract}

Keywords Mobile communications - Patent statistics · Technological capability · TLE

\section{Cho $(\varangle) \cdot$ M. Park}

Department of Business and Technology Management,

Korea Advanced Institute of Science and Technology,

291 Daehak-ro, Yuseong-gu, Daejeon 305-701, Korea

e-mail: cho19@keit.re.kr

M. Park

e-mail: imcpark@kaist.ac.kr

\section{Introduction}

Information and communication technology (ICT) has been a key driving force in development and diffusion for knowledge-based economies [1]. As competition in ICT innovation among nations becomes more intense in the theoretical and social paradigms of a national innovation system, there are growing demands for improved judgment, evaluation, and prediction of ICT capacity in order to improve a nation's competitiveness [2-4].

Technological competitiveness is important for national economic performance, particularly with national introductions of stronger intellectual property rights, regulatory harmonization and standardization, and the worldwide spread of emerging ICT [5,6]. Technological capabilities are the conceptual-level elements that capture technological competitiveness in operation. A technological level can be defined as the relative technological capability to use technological knowledge efficiently and refers to the extent to which technological knowledge is accumulated, invested in, produced, and innovated. A technological level refers to the present status of technological accumulation and accomplishment based on past technological activities $[4,7]$. Therefore, a technological-level evaluation (TLE) can be defined statistically by estimating and assessing the technological status in terms of technological performance and capacity at the time of the evaluation.

Several new models for national TLE have recently been developed, with the research being enabled by a certain theoretical and empirical consensus about the nature of technology [8]. There is significant recent research about the constitution of composite statistics for TLEs at a national level. Policy analysts and academic researchers both need new and improved measures at the technological level regarding the 
performance of nations in understanding technological, economic, and social developments.

For a long time, the research domain of technological innovation and strategy has suffered from a lack of proper statistical data, forcing most of the earlier studies to focus on conceptual and/or qualitative approaches [9]. Patent statistics have recently been used by technicians, researchers, and economists in the field of technological innovation to analyze current directions of, and to forecast, technological development in terms of well-defined patent databases (DBs). Patents are regarded as an essential source of commercial knowledge, and almost $80 \%$ of all technological information can be found in patent-application data [10]. Furthermore, according to statistics released by the World Intellectual Property Organization (WIPO), 90-95\% of economically valuable human-innovation results are retained in patent DBs [11]. In an increasing number and variety of studies, patent statistics have been used to evaluate research and development (R\&D) performance and production. Tools based on patent statistics are used to analyze $R \& D$ production and are increasingly being used for R\&D performance evaluation.

Mobile communications can be considered to be the fastest growing industry of all over the past decade. Mobile telephones have become daily necessities for billions of people, and they are increasingly being used in both developed and developing nations. There were 2.21 billion mobile subscribers worldwide in 2005, with 6.84 billion expected by 2013 [12].

In this paper, we evaluate the technological level of mobile communications using patent statistics analysis at a national level. In particular, we perform a TLE of 3G, 3G transitional, and $4 \mathrm{G}$ mobile communications technologies for five nations; namely the US, EU, Japan, China, and Korea, and we consider the EU a single nation to simplify the evaluation.

The paper is organized as follows. Section 2 outlines research approaches, reviewing the literature on TLE and patent analysis. Section 3 describes the research model for TLE using patent statistics. An empirical analysis and the results of a TLE for mobile communications are presented in Sect. 4. Section 5 contains a discussion and conclusions.

\section{Research approaches and literature review}

\subsection{The demands for data-based TLEs}

Various international organizations and entities have made announcements on worldwide technological and economic competitiveness. The International Institute of Management Development (IMD), the Research And Development Corporation (RAND), the United Nations Development Program (UNDP), the United Nations Industrial Development Organization (UNIDO), and the World Economic Forum (WEF) release national competitiveness reports periodically that measure national capacities to improve economic development and living standards. These reports deal with technological competitiveness, and most use patent statistics as a solid basis for national innovative capacity [13]. In addition, major developed and developing nations conduct TLEs when establishing strategies for national R\&D programs and monitoring technological trends. Examples of these reports include the 'National Core Technology Report (US, 2005)', the 'Survey on 20-year Technology Predictions for the Future (China, 2008)', and the 'Survey on Research and Development Levels (Japan, 2011)'.

In Korea, government agencies and institutes have conducted studies involving TLE, as shown in Table 1. These involved peer reviews and expert surveys at a qualitative technological level. In general, it is recognized that peer or expert surveys have various limitations and shortcomings. In particular, the outcomes of a peer review process may contain errors nearly $50 \%$ because of human chance and randomness [14-16]. However, patents can be regarded as realizations of technologies, and patent statistics would therefore be sufficient for TLEs $[17,18]$. Moreover, several new measures of national technological capability using patent statistics have been developed recently, such as 'ArCo' [19] and the 'Patent Asset Index' [20].

With this background, we propose a TLE method based on composite and quantitative patent statistics. TLEs based on patent statistics would be expected to apply as supplementary tools in the peer-review process and even to begin to replace the peer-review method.

\subsection{Patent statistics for TLE}

A patent DB can offer valuable information and knowledge for technological strategy planning and R\&D funding. It is also constructed from patent statistics that involve the analysis of successful applications in high-tech industries such as ICT and biotechnology.

Patent statistics analysis techniques have also been used to reflect technological innovation levels in a nation, an industry, or a firm [24]. Within many economics and technology management disciplines, patent statistics have become well defined and established as a proxy factor for the measure of technological capacity and accepted as (albeit imperfect) statistics for innovation and R\&D production in the absence of more robust measures [25-27]. Patent application and registration is also a system that companies and institutes use to perfect their technological innovations, and for legal reasons, patent-filing information is systematically registered by national government offices [28].

Much research has shown a positive relationship between patenting and R\&D institute or company performance, provided that patent applications are weighted according to their quantity and quality $[25,29]$. The patent statistics used in this 
Table 1 Recent Korean reports involving TLEs

\begin{tabular}{|c|c|c|c|}
\hline & KISTEP [21] & KEIT [22] & DTaQ [23] \\
\hline Title & $\begin{array}{l}\text { Report on a science- } \\
\text { and-technology-level } \\
\text { evaluation in } 2010 \\
\text { [21] }\end{array}$ & $\begin{array}{l}\text { Survey report on } \\
\text { industrial } \\
\text { technology in } 2011 \\
{[22]}\end{array}$ & $\begin{array}{l}\text { Survey report on } \\
\text { defense technology } \\
\text { in } 2012 \text { [23] }\end{array}$ \\
\hline Purpose & $\begin{array}{l}\text { Analysis of the current } \\
\text { status of effective } \\
\text { national R\&D } \\
\text { establishments }\end{array}$ & $\begin{array}{l}\text { Preliminary research } \\
\text { on industrial } \\
\text { technology } \\
\text { planning }\end{array}$ & $\begin{array}{l}\text { Identification of } \\
\text { future potential } \\
\text { defense technology }\end{array}$ \\
\hline Evaluation subject & $\begin{array}{l}95 \text { key technologies for } \\
\text { the nation }\end{array}$ & $\begin{array}{l}117 \text { core } \\
\text { technologies for } \\
\text { the nation }\end{array}$ & $\begin{array}{l}24 \text { weapons systems } \\
\text { for the nation }\end{array}$ \\
\hline Subject nations & $\begin{array}{l}\text { US, Japan, EU, China, } \\
\text { Korea (5 nations) }\end{array}$ & $\begin{array}{l}\text { US, Japan, EU, } \\
\text { China, Korea (5 } \\
\text { nations) }\end{array}$ & $\begin{array}{l}\text { US, France, Russia, } \\
\text { UK, German, } \\
\text { Japan, Israel, } \\
\text { China, Italy, } \\
\text { Canada, Sweden, } \\
\text { India, Spain, South } \\
\text { Africa, Turkey, } \\
\text { Korea (16 nations) }\end{array}$ \\
\hline Method & $\begin{array}{l}\text { Poll of organizations, } \\
\text { groups, and } \\
\text { corporations }\end{array}$ & $\begin{array}{l}\text { Expert Delphi } \\
\text { Survey }\end{array}$ & $\begin{array}{l}\text { Expert Delphi } \\
\text { Survey }\end{array}$ \\
\hline
\end{tabular}

KISTEP is an institute for planning and evaluating science and technology at a national level under the Ministry of Science, ICT and Future Planning. KEIT is an agency for planning and evaluating industrial technology at a national level under the Ministry of Trade, Industry and Energy. $\mathrm{DTaQ}$ is an agency for evaluating defense technology and managing quality assurance of military supplies under the Defense Acquisition Program Administration

Table 2 Literature on patent statistics

\begin{tabular}{|c|c|c|c|c|c|c|c|c|c|c|c|}
\hline \multirow[t]{2}{*}{ Studies } & \multicolumn{11}{|c|}{ Patent statistics } \\
\hline & NP & PGPA & PCPA & $\mathrm{NF}$ & $\mathrm{CI}$ & CII & $\mathrm{TS}$ & TCT & $\mathrm{NC}$ & TI & RPA \\
\hline Huang et al. [47] & $*$ & & & & $*$ & * & & $*$ & & $*$ & \\
\hline Park et al. [9] & $*$ & & & & $*$ & & & & & & \\
\hline Guellec and Bruno [54] & $*$ & & & $*$ & & & & & & & \\
\hline Ernst [24] & $*$ & $*$ & $*$ & $*$ & $*$ & & & & & & \\
\hline CHI Research [48] & $*$ & $*$ & $*$ & & $*$ & $*$ & $*$ & $*$ & & & \\
\hline Breitzman and Thomas [50] & $*$ & & & & & & & & $*$ & & \\
\hline Archibugi and Pianta [28] & & & & $*$ & $*$ & & & & & & \\
\hline Schmoch [55] & & & & & & & & & & & $*$ \\
\hline Griliches [25] & $*$ & & & & $*$ & * & & $*$ & & $*$ & \\
\hline Trajtenberg [49] & & & & & & & & & $*$ & & \\
\hline Chia [53] & $*$ & $*$ & & & $*$ & $*$ & & $*$ & $*$ & & \\
\hline Narin [52] & $*$ & & & & & * & & $*$ & & & \\
\hline
\end{tabular}

NP is the number of patents. PGPA is percentage growth of patents in the area. PCPA is the percentage of company patents in the area. NF is the number of families. CI is the citations per patent. CII is the current impact index. TS is the technology strength. TCT is the technology cycle time. TI is the technology independence. RPA is the revealed patent advantage

research include the numbers, citations, registrations, and technological and international scope of the patent applications.

Table 2 summarizes an important set of statistics used to analyze technological strategy. The statistics were proposed for the evaluation of competitive positions in: number of patent applications (NP, PGPA, PCPA), patent citations (CI, CII, TS, TCT), number of families (NF), number of citations (NC), technology independence (TI), and revealed patent advantage (RPA) [30].

\section{Research method}

\subsection{Research process}

As shown in Fig. 1, our TLE based on patent statistics for mobile communications technologies involved six steps. First, we developed a model for the TLE and made an overall plan for its analysis. Second, we established a technological classification for mobile communications technologies, and we identified keywords and a search formula from the techno- 
(1) TLE modeling and planning

\section{$\downarrow$}

(2) Technology classification and keyword drawing

$$
\downarrow
$$

(3) Establishing the patent DB and screening

\section{$\downarrow$}

(4) Weighting of TLE statistics

\section{$\downarrow$}

(5) Data analysis for TLE

\section{$\downarrow$}

(6) Result validation and discussion

Fig. 1 A research process for TLE

logical classification to draw out some target patent statistics. Third, we established a patent DB in mobile communications to analyze the TLE after screening out noise with the help of technical experts. Fourth, we identified the weights for patent evaluation statistics via a rational weighting method. Fifth, we computed the real TLE by using weighted patent statistics. Finally, we investigated validation of the TLE model and discussed the results, thereby suggesting how to use the results to create an $R \& D$ policy strategy.

\subsection{Patent statistics for TLE}

We defined a Patent AIMC ${ }^{1}$ model for a TLE based on quantitative and qualitative patent statistics. The patent statistics used in the Patent AIMC model are the PAI, PII, PMI, and PCI, as described in Table 3. The selected patent statistics are empirically derived from literature reviews and patent professionals survey which have shown a positive relationship between patenting and technological capability if patent applications are weighted according to their quantity and quality $[25,29]$. The appropriate and weighted patent applications quantity statistics are patent activity and intensity index. Also, the appropriate and weighted patent applications quality statistics are patent market-power and citation index.

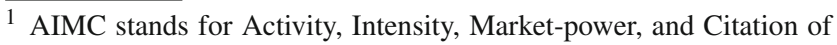
patent.
A TLE based on the Patent AIMC model can be computed by Eq. (1).

$$
\begin{aligned}
\text { Patent AIMC }= & \mathrm{W} \times \mathrm{P}^{\prime}=\left(\mathrm{W}_{1} \times \mathrm{PAI}\right)+\left(\mathrm{W}_{2} \times \mathrm{PII}\right) \\
& +\left(\mathrm{W}_{3} \times \mathrm{PMI}\right)+\left(\mathrm{W}_{4} \times \mathrm{PCI}\right),
\end{aligned}
$$

where $\mathrm{W}=\left(\mathrm{W}_{1}, \mathrm{~W}_{2}, \mathrm{~W}_{3}, \mathrm{~W}_{4}\right), \mathrm{P}=$ (PAI, PII, PMI, PCI). $\mathrm{W}$ is a weight vector, and $\mathrm{P}$ is a patent statistics vector. (1)

\subsection{Determination of weights for patent statistics}

As for any method involving nonlinear values and dimensionless processes, the weights of each statistic need to be determined, the goal being to reflect the function and significance of the various evaluation statistics in multiple-decision problems [31]. Methods for the determination of weights fall into two categories. One category involves identifying weights by data analysis, determining the weights via correlations or the variations between statistics. Examples include the mean squared method, factor analysis, and using average or equal means. This approach avoids deviations caused by human randomness factors, but fluctuations can depend on the data. The other category involves identifying weights by a relatedexpert survey, determining the weights mainly via comprehensive expert-consultation scores. This approach has some subjectivity but has been used in a wide variety of fields that have given rational solutions. Examples include the analytic hierarchy process (AHP), the Delphi Survey, and questionnaire investigations. To acquire generality and to avoid variability caused by giving weights that depend on specific data, we had to select a technique that distributes the weights for TLE statistics rationally.

Satty [32] originally developed a pairwise comparison method based on the analytic hierarchical structure of the target problem. An inverse pairwise comparison matrix was devised based on a numerical evaluation scale of 1-9 [32]. In various studies of uncertainty with vagueness, impression, and complexity, expert opinion can provide a rational method by which human knowledge for making decisions is incorporated in an adaptive and flexible manner [33-35]. Therefore, the weights for the TLE statistics could be rationally obtained by an AHP technique based on expert systems.

\section{Results and empirical analysis}

\subsection{Patent statistics for TLE in mobile communications}

We performed a TLE for the US, EU, Japan, China, and Korea using patent statistics for 3G, 3G transitional, and 4G mobile communications over the past decade. We analyzed patent data for public, notified, or registered patent applications filed with the national patent offices in the US, EU, 
Table 3 Selected patent statistics for TLE

\begin{tabular}{|c|c|c|c|}
\hline Term & Statistics & Definition & Technical meaning \\
\hline PAI & Patent activity index & $\begin{array}{l}\text { Patent applications (PA) of nation } \\
\mathrm{i} \text { in technological field (TF) } \mathrm{F} \\
\Rightarrow \mathrm{PA}_{i F} / \mathrm{PA} \text { for all competitors } \\
\text { in } \mathrm{F} \\
\text { (technology share based on } \mathrm{PA} \text { ) }\end{array}$ & $\begin{array}{l}\text { Extent of R\&D expenditure by } i \text { in } \\
F \text { (interest of } i \text { in } F \text { ) or } \\
\text { competitive technological } \\
\text { position of } i \text { in } F \text { (quantitative) }\end{array}$ \\
\hline PII & Patent intensity index & $\mathrm{PA}_{i F} /$ i's total PA & $\begin{array}{l}\text { Importance of } F \text { to i (R\&D } \\
\text { emphasis or concentration, } \\
\text { quantitative) }\end{array}$ \\
\hline PMI & Patent market-power index & $\begin{array}{l}\text { Size of patent family }(\mathrm{PF}) \text { and } \\
\text { share of patents for triad (US, } \\
\text { JP, EPO) } \mathrm{PA}_{i k}\end{array}$ & $\begin{array}{l}\text { Economic quality of i's PA } \\
\text { (international scope of } \\
\text { protection) }\end{array}$ \\
\hline PCI & Patent citation index & $\begin{array}{l}\text { Average citation frequency of } \\
\mathrm{PA}_{i k}: \mathrm{PC}_{i F}\end{array}$ & $\begin{array}{l}\text { Economic quality of i's PA } \\
\text { (competitive technological } \\
\text { strength of i in F) }\end{array}$ \\
\hline
\end{tabular}

Table 4 Overview of patent statistics analysis

\begin{tabular}{|c|c|}
\hline & Contents \\
\hline Target technologies & $\begin{array}{l}\text { 3G, } 3 \mathrm{G} \text { transitional, and } 4 \mathrm{G} \text { mobile } \\
\text { communications }\end{array}$ \\
\hline Nations & US, EU, Japan, China, and Korea \\
\hline \multirow[t]{2}{*}{ Data } & Patent application numbers: 25,623 \\
\hline & $\begin{array}{l}\text { DB of public, notified, or registered patents: } \\
\text { USPTO, EPO, JPO, SIPO, and KIPO } \\
\text { Inventor's nationality: US, EU, JP, CN, or } \\
\text { KR } \\
\text { Period: Jan. 1, 1999-Dec. 31, } 2011\end{array}$ \\
\hline Analysis time point & Nov. 1, 2012-Nov. 5, 2012 \\
\hline Evaluation statistics & $\begin{array}{l}\text { Patent numbers, Patent citations: PAI, PII, } \\
\text { PMI, PCI }\end{array}$ \\
\hline
\end{tabular}

Japan, China, and Korea from January 1, 1999 to December 31, 2011, with respect to the inventors' nationalities. Table 4 shows an overview of the patent statistics analysis for the TLE among nations in mobile communications.

The analysis targets for technology classification in mobile communications are 3G, 3G transitional, and 4G. The general definition of $3 \mathrm{G}$ systems was formally completed by the International Telecommunication Union Radiocommunication Sector (ITU-R) in 1997. To create a collaboration body for the various telecommunications associations, the 3G Partnership Project (3GPP) was established in 1998. 3G mobile communications are implemented by a generation of network standards for mobile phones and communications services fulfilling the International Mobile Telecommunications-2000 (IMT-2000) specifications. To meet the IMT-2000 standards defined by the ITU, a system is required to provide peak data rates of at least $0.2 \mathrm{Mbit} / \mathrm{s}$

Table 5 Technology classifications of mobile communications

\begin{tabular}{lll}
\hline Generations & Families & Mobile communications technologies \\
\hline 3G (IMT-2000) & $3 \mathrm{GPP}$ & UMTS (UTRAN), WCDMA-FDD, WCDMA-TDD, UTRA-TDD (TD-SCDMA) \\
& $3 \mathrm{GPP} 2$ & CDMA2000 1xEV-DO Release (TIA/IS-856) \\
3G transitional (3.5G, 3.75G, 3.9G) & $3 \mathrm{GPP}$ & HSDPA, HSUPA, HSPA+, LTE (E-UTRA) \\
& $3 \mathrm{GPP} 2$ & CDMA2000 1xEV-DO Revision A (TIA/EIA/IS-856-A), CDMA2000 1xEV-DO \\
& & Revision B (TIA/EIA/IS-856-B), DO Advanced \\
& IEEE & Mobile WiMax (IEEE 802.16e), WiBro, Flash-OFDM, IEEE 802.20 \\
4G (IMT-Advanced) & 3GPP & LTE advanced (E-UTRA), TD-LTE advanced \\
& IEEE & WiMax advanced (IEEE 802.16m), WiMax2, WiBro evolution
\end{tabular}

3GPP is the 3rd Generation Partnership Project. 3GPP2 is the 3rd Generation Partnership Project. IEEE is the Institute of Electrical and Electronics Engineers. UMTS is the universal mobile telecommunications system. WCDMA is wideband code-division multiple access. FDD is frequencydivision duplex. TDD is time-division duplex. UTRA is UMTS terrestrial radio access. TD-SCMDA is time-division-synchronous CDMA. EV-DO is evolution-data optimized. HSDPA is high-speed downlink packet access. HSUPA is high-speed uplink packet access. E-UTRA is evolved UTRA. TIA/EIA/IS is Telecommunications Industry Association/Electronics Industry Association/industry standard. WiMax is world interoperability for microwave access. WiBro is wireless broadband. LTE is long-term evolution 
Table 6 Weights for the Patent AIMC model for TLE

\begin{tabular}{ll}
\hline Patent statistics & Weights \\
\hline PAI & 0.253 \\
PII & 0.201 \\
PMI & 0.304 \\
PCI & 0.242 \\
Total & 1.000 \\
\hline
\end{tabular}

[36-39]. The 3G transitional release, sometimes denoted $3.5 \mathrm{G}, 3.75 \mathrm{G}$, or $3.9 \mathrm{G}$, provides mobile broadband access of several Mbit/s to smartphones and mobile modems in laptop computers and tablets [40-42]. The 4G mobile communications standard is the successor to the $3 \mathrm{G}$ and $3 \mathrm{G}$ transitional network standards [43]. The $4 \mathrm{G}$ system provides mobile ultrabroadband Internet access to laptop computers via universal serial bus (USB) wireless modems, to smartphones, and to other mobile devices [44-46,57]. Two recent commercial 4G systems are the Mobile WiMax standard (firstly in Korea in 2006), and the first-release long-term evolution (LTE) standard in Scandinavia in 2009. In the US, Sprint Nextel deployed Mobile WiMax networks in 2008, and MetroPCS was the first operator to offer LTE services in 2010. USB wireless modems have been available since 4G's inception, while WiMax smartphones have been available since 2010 and LTE smartphones since 2011.
Based on the published literature, Table 5 shows the technology classifications of mobile communications standards used to evaluate technological levels among nations [44].

\subsection{Weights for TLE statistics using patent statistics}

We conducted a survey of selected experts and calculated weights for the TLE statistics based on the AHP technique with an expert survey using the 'Expert Choice ver. 2000' program [56]. The subjects of the AHP survey were 48 experts from professional companies, research institutes, patent agencies, and universities. They were surveyed online during the period November 22, 2012 - November 24, 2012. Table 6 shows the resulting weights for the patent statistics used in the TLE.

\subsection{Empirical results for TLE in mobile communications}

We used a keyword extraction method to identify those public, notified, and registered patents whose 25,623 applications had been filed with the patent offices in the US, EU, Japan, China, and Korea from January 1, 1999 to December 31, 2011 with respect to technology classifications in mobile communications. We analyzed and evaluated four patent statisticsnamely, PAI, PII, PMI, and PCI—with respect to the inventors' nationalities.

Table 7 Aggregate patent statistics in mobile communications, 1999-2011

\begin{tabular}{|c|c|c|c|c|c|c|c|}
\hline Technologies & Statistical items & US & EU & Japan & China & Korea & Total \\
\hline \multirow[t]{5}{*}{ Mobile communications } & \# of patent applications & 8,547 & 4,160 & 2,977 & 4,880 & 5,059 & 25,623 \\
\hline & \# of patent families & 38,806 & 24,214 & 19,741 & 13,951 & 21,828 & 118,540 \\
\hline & $\#$ of triadic patents & 2,384 & 1,641 & 2,143 & 743 & 1,558 & 8,469 \\
\hline & \# of patent citations (USPTO) & 4,533 & 5,053 & 383 & 89 & 923 & 10,981 \\
\hline & \# of patent applications (USPTO) & 1,289 & 1,065 & 193 & 70 & 363 & 2,980 \\
\hline \multirow[t]{5}{*}{$3 \mathrm{G}$} & \# of patent applications & 4,313 & 2,573 & 1,758 & 2,472 & 2,576 & 13,692 \\
\hline & \# of patent families & 22,027 & 15,671 & 12,929 & 7,485 & 12,276 & 70,388 \\
\hline & $\#$ of triadic patents & 1,432 & 1,014 & 1,381 & 406 & 914 & 5,147 \\
\hline & \# of patent citations (USPTO) & 3,731 & 4,881 & 271 & 72 & 624 & 9,579 \\
\hline & \# of patent applications (USPTO) & 781 & 886 & 104 & 42 & 179 & 1,992 \\
\hline \multirow[t]{5}{*}{$3 \mathrm{G}$ transitional } & \# of patent applications & 3,821 & 1,444 & 1,122 & 2,167 & 2,283 & 10,837 \\
\hline & \# of patent families & 15,051 & 7,751 & 6,208 & 5,870 & 8,574 & 43,454 \\
\hline & \# of triadic patents & 860 & 577 & 697 & 315 & 572 & 3,021 \\
\hline & \# of patent citations (USPTO) & 630 & 172 & 112 & 17 & 298 & 1,229 \\
\hline & \# of patent applications (USPTO) & 465 & 176 & 87 & 27 & 176 & 931 \\
\hline \multirow[t]{5}{*}{$4 \mathrm{G}$} & \# of patent applications & 413 & 143 & 97 & 241 & 200 & 1,094 \\
\hline & \# of patent families & 1,728 & 792 & 604 & 596 & 978 & 4,698 \\
\hline & \# of triadic patents & 92 & 50 & 65 & 22 & 72 & 301 \\
\hline & \# of patent citations (USPTO) & 172 & - & - & - & 1 & 173 \\
\hline & \# of patent applications (USPTO) & 43 & 3 & 2 & 1 & 8 & 57 \\
\hline
\end{tabular}


Table 8 TLE among nations, based on patent statistics for mobile communications, 1999-2011

\begin{tabular}{|c|c|c|c|c|c|c|c|}
\hline Technologies & Statistics & US & EU & Japan & China & Korea & Total \\
\hline \multirow[t]{6}{*}{ Mobile communications } & PAI & 0.334 & 0.162 & 0.116 & 0.190 & 0.197 & 1.000 \\
\hline & PII & 0.212 & 0.188 & 0.187 & 0.213 & 0.199 & 1.000 \\
\hline & PMI & 0.188 & 0.241 & 0.274 & 0.118 & 0.179 & 1.000 \\
\hline & PCI & 0.250 & 0.337 & 0.141 & 0.090 & 0.181 & 1.000 \\
\hline & Patent AIMC & 0.245 & 0.234 & 0.185 & 0.149 & 0.188 & 1.000 \\
\hline & Patent AIMC (transform to $100 \%$ ) & 100.0 & 95.6 & 75.4 & 60.9 & 76.9 & $\%$ \\
\hline \multirow[t]{6}{*}{$3 \mathrm{G}$} & PAI & 0.315 & 0.188 & 0.128 & 0.181 & 0.188 & 1.000 \\
\hline & PII & 0.185 & 0.227 & 0.216 & 0.186 & 0.187 & 1.000 \\
\hline & PMI & 0.185 & 0.252 & 0.260 & 0.127 & 0.176 & 1.000 \\
\hline & PCI & 0.264 & 0.304 & 0.144 & 0.095 & 0.193 & 1.000 \\
\hline & Patent AIMC & 0.237 & 0.243 & 0.190 & 0.145 & 0.185 & 1.000 \\
\hline & Patent AIMC (transform to $100 \%$ ) & 97.4 & 100.0 & 78.0 & 59.4 & 76.1 & $\%$ \\
\hline \multirow[t]{6}{*}{ 3G transitional } & PAI & 0.353 & 0.133 & 0.104 & 0.200 & 0.211 & 1.000 \\
\hline & PII & 0.216 & 0.168 & 0.182 & 0.215 & 0.218 & 1.000 \\
\hline & PMI & 0.185 & 0.252 & 0.260 & 0.127 & 0.176 & 1.000 \\
\hline & PCI & 0.228 & 0.164 & 0.217 & 0.106 & 0.285 & 1.000 \\
\hline & Patent AIMC & 0.244 & 0.184 & 0.194 & 0.158 & 0.220 & 1.000 \\
\hline & Patent AIMC (transform to $100 \%$ ) & 100.0 & 75.3 & 79.6 & 64.8 & 90.0 & $\%$ \\
\hline \multirow[t]{6}{*}{$4 \mathrm{G}$} & PAI & 0.378 & 0.131 & 0.089 & 0.220 & 0.183 & 1.000 \\
\hline & PII & 0.237 & 0.168 & 0.160 & 0.242 & 0.194 & 1.000 \\
\hline & PMI & 0.179 & 0.238 & 0.267 & 0.106 & 0.210 & 1.000 \\
\hline & PCI & 0.970 & - & - & - & 0.030 & 1.000 \\
\hline & Patent AIMC & 0.432 & 0.139 & 0.136 & 0.137 & 0.156 & 1.000 \\
\hline & Patent AIMC (transform to $100 \%$ ) & 100.0 & 32.2 & 31.4 & 31.6 & 36.1 & $\%$ \\
\hline
\end{tabular}

The results of evaluating the Patent AIMC in overall mobile communications technology are given in Tables 7 and 8, showing that the US is the leader (100.0\%), the EU is second (95.6\%), Korea is third (76.9 \%), Japan is fourth $(75.4 \%)$, and China is fifth $(60.9 \%)$. Specifically, the US is stronger than other nations in patent activity, the $\mathrm{EU}$ is stronger than other nations in patent citation, Japan is stronger than other nations in patent market power, and China is stronger than other nations in patent intensity. In $3 \mathrm{G}$ mobile communications technology, the EU is the leader, but the US is the $3 \mathrm{G}$ transitional and $4 \mathrm{G}$ leader.

Korea had fourth position in $3 \mathrm{G}$, but second position in $3 \mathrm{G}$ transitional and $4 \mathrm{G}$ mobile communications technologies according to the strategic investment of national and industrial R\&D funding to mobile communications. In R\&D strategy of Korea with the goal of having the highest mobile phone and higher mobile systems market share from the viewpoint of patent AIMC, we could suggest more amount of national R\&D funding to beyond $4 \mathrm{G}$ or $5 \mathrm{G}$ mobile communications technologies to create and acquire higher patents market power and citation like US, EU, Japan.

\subsection{Comparison and validation}

We checked the consistency of the TLE measures, by performing an empirical validation study. We compared the Patent AIMC and an Expert Delphi Survey among nations given in Table 9. The Expert Delphi Survey included reallocated results for selected mobile communications technologies from KEIT's 'Research report on total industrial technology level in 2011', and the strategic domain of nextgeneration mobile communications was surveyed by 495 researchers, professors, and industrial technicians in Korea [22]. Although we dealt with typical interval data, the small sample did not justify using a normal distribution. Therefore, our method of construction of the statistics allowed only comparison between the rankings, and not absolute values. Accordingly, we checked the similarity between the Patent AIMC and Expert Delphi Survey with respect to the rankings of nations. For this purpose, a rank correlation (Spearman statistic) was employed because it did not require a normal distribution of data.

Table 10 shows the correlations among the rankings for the nations available for each pair of statistics. This allowed 
Table 9 Relative score summary for the Patent AIMC and Expert Delphi Survey among nations in mobile communications, 1999-2011

\begin{tabular}{|c|c|c|c|}
\hline Technology & Nation & Patent AIMC & $\begin{array}{l}\text { Expert Delphi } \\
\text { Survey }\end{array}$ \\
\hline \multirow[t]{5}{*}{ Mobile communications } & US & 100.0 & 100.0 \\
\hline & $\mathrm{EU}$ & 95.6 & 96.9 \\
\hline & Japan & 75.4 & 83.0 \\
\hline & China & 60.9 & 70.3 \\
\hline & Korea & 76.9 & 85.6 \\
\hline \multirow[t]{5}{*}{$3 \mathrm{G}$} & US & 97.4 & 98.4 \\
\hline & $\mathrm{EU}$ & 100.0 & 100.0 \\
\hline & Japan & 78.0 & 87.1 \\
\hline & China & 59.4 & 69.7 \\
\hline & Korea & 76.1 & 83.8 \\
\hline \multirow[t]{5}{*}{ 3G transitional } & US & 100.0 & 100.0 \\
\hline & $\mathrm{EU}$ & 75.3 & 96.2 \\
\hline & Japan & 79.6 & 77.1 \\
\hline & China & 64.8 & 71.8 \\
\hline & Korea & 90.0 & 85.4 \\
\hline \multirow[t]{5}{*}{$4 \mathrm{G}$} & US & 100.0 & 100.0 \\
\hline & $\mathrm{EU}$ & 32.2 & 92.7 \\
\hline & Japan & 31.4 & 76.5 \\
\hline & China & 31.6 & 77.1 \\
\hline & Korea & 36.1 & 87.6 \\
\hline
\end{tabular}

The Expert Delphi Survey included the recalculated results for selected mobile communications technologies from KEIT's 'Research report on total industrial technology level in 2011'. The strategic technology domain of next-generation mobile communications was surveyed by 495 researchers, professors, and industrial technicians in Korea

two considerations of all nations in the Patent AIMC-Expert Delphi Survey. As shown in Table 10, the Patent AIMC and Expert Delphi Survey were mutually interdependent, showing that the correlation $(0.727)$ was significant at the 0.01 level (2-tailed). Therefore, although different TLE methodologies lead to somewhat different results in general, we found that the Expert Delphi Survey could be replaced rationally by the Patent AIMC.

\section{Conclusion and discussion}

\subsection{Limitation}

The TLE method based on patent statistics described in this paper has some limitations. First, we did not thoroughly justify the patent statistics (Patent AIMC) because we considered only those quantitative and qualitative patent statistics that had simple, specific, distributed, and relative features described in the literature [45]. Second, we identified subjectively the weights of patent statistics by an AHP method via a selected-expert survey. Data-oriented methods such as the mean-square method and factor analysis avoid some variations caused by human randomness factors, but they also contain fluctuations that depend on the data. We therefore have to review and consider further the weighting of TLE statistics. Third, the patent data used our empirical research were incomplete for mobile communications technologies. Patent announcements usually appear two years after patent applications and are then only gathered and screened by keyword extraction methods using technology classifications for mobile communications technologies.

\subsection{Conclusion}

In this paper, we show that a TLE based on patent statistics can lead to a consistent relative evaluation of the attainment level of technology, and this evaluation can be used to identify the technological advancement among nations. Furthermore, these methodologies can provide a more objective TLE than subjective Expert Delphi, or peer-review systems. Our proposed method would be extended to not only mobile communications field but also other technical fields like robotics, software, semiconductors, etc. Our proposal involving synthetic TLE statistics (the Patent AIMC) using patent statistics at a national level could also be applied to researchers, institutions, companies, and technological domains.

Our empirical research results present a faithful and consistent picture on the national status of innovative activities and performance in mobile communications technologies

Table 10 Spearman rank correlations for the Patent AIMC and Expert Delphi Survey with respect to mobile communications

\begin{tabular}{llll}
\hline & Spearman's rho & Patent AIMC & Expert Delphi Survey \\
\hline Patent AIMC & Correlation coefficient & 1.000 & $0.727^{\mathrm{a}}$ \\
& Sig. (2-tailed) & & 0.000 \\
& $\mathrm{~N}$ & 20 & 20 \\
Expert Delphi Survey & Correlation coefficient & $0.727^{\mathrm{a}}$ & 1.000 \\
& Sig. (2-tailed) & 0.000 & 20 \\
& $\mathrm{~N}$ & 20 & 20
\end{tabular}

${ }^{a}$ Correlation is significant at the $0.01 \%$ level (2-tailed) 
among major nations of the world. In overall mobile communications technology, the US is a technological innovation leader, the EU is second, Korea is third, Japan is fourth, and China is in last place. In $3 \mathrm{G}$ mobile communications technology, the EU is the technological innovation leader, but the US is the $3 \mathrm{G}$ transitional and $4 \mathrm{G}$ leader. In particular, in the Asia zone, Japan was a leader in $3 \mathrm{G}$, but now Korea has more innovative power in $3 \mathrm{G}$ transitional and $4 \mathrm{G}$ technologies than Japan and China.

\subsection{Further study}

The validity of the proposed TLE statistics and weights are not sufficiently checked by comparison with other studies. In future work, we plan to establish consolidated patent and bibliometric statistics for measuring national technological innovation and scientific advancement by more literature reviews and statistical data analyses in various domains.

We considered only a TLE based on patent statistics in mobile communications. We are eager to review and compare it with statistical analyses of levels of production, sales, market shares, trades, and domain sites in the mobile communications industry. Each nation follows a different path in science research and technology development because of differences in $R \& D$ policy, professional human resources, $R \& D$ funding, and infrastructure, etc. Therefore, a TLE should consider the characteristics of each nation's science and technology and develop strategies that are tailored to each nation's status in science and technology. The identification of technological and industrial features for use in a TLE would also be a practical and interesting topic for future research.

Open Access This article is distributed under the terms of the Creative Commons Attribution License which permits any use, distribution, and reproduction in any medium, provided the original author(s) and the source are credited.

\section{References}

1. Foray, D., Lundvall, B.A.: The Knowledge Based Economy. OECD, Paris (1997)

2. Watts, R.J., Porter, A.L.: Innovation forecasting. Technol. Forecast. Soc. 56(1), 25-47 (1997)

3. Karlsson, C., Maier, G., Trippl, M., Siedschlag, I., Owen, R., Murphy, G.: ICT and Regional Economic Dynamics: A Literature Review. Publications Office of the European Union, Luxembourg, JRC Scientific and Technical Reports (2010)

4. Ryu, J., Byeon, S.C.: Technology level evaluation methodology based on the technology growth curve. Technol. Forecast. Soc. 78(6), 1049-1059 (2011)

5. Glimstedt, H.: Competitive dynamics of technological standardization: the case of third generation cellular communications. Ind. Innov. 8(1), 49-78 (2001)

6. UNIDO: Industrial Development Report 2005, Executive Summary. UNIDO, Vienna (2005)
7. Solow, R.M.: Technical change and the aggregate production function. Rev. Econ. Stat. 39(3), 312-320 (1957)

8. Archibugi, D., Coco, A.: Measuring technological capabilities at the country level: a survey and a menu for choice. Res. Policy 34(2), 175-194 (2005)

9. Park, Y., Yoon, B., Lee, S.: The Idiosyncrasy and dynamism of technological innovation across industries: patent citation analysis. Technol. Soc. 27(4), 471-485 (2005)

10. Blackman, M.: Provision of patent information: a national patent office perspective. World Pat. Inf. 17(2), 115-123 (1995)

11. Yu, W.D., Lo, S.S.: Patent analysis-based fuzzy inference system for technological strategy planning. Autom. Constr. 18(6), 770-776 (2009)

12. International Telecommunication Union (ITU): The ITU register. http://www.itu.int (2013). Accessed 9 November 2013

13. Furman, J.L., Porter, M.E., Stern, S.: The determinants of national innovative capacity. Res. Policy 31(6), 899-933 (2002)

14. Chubin, D.E., Hackett, E.J.: Peerless Science: Peer Review and US Science Policy. Suny Press, New York (1990)

15. Nederhof, A.J.: The Validity and Reliability of Evaluation of Scholarly Performance. Handbook of Quantitative Studies of Science and Technology, pp. 193-228. Elsevier, North-Holland (1988)

16. Aksnes, D.W., Taxt, R.E.: Peer reviews and bibliometric indicators: a comparative study at a Norwegian university. Res. Eval. 13(1), 33-41 (2004)

17. Tijssen, R.J.: Global and domestic utilization of industrial relevant science: patent citation analysis of science-technology interactions and knowledge flows. Res. Policy 30(1), 35-54 (2001)

18. Wallin, J.A.: Bibliometric methods: pitfalls and possibilities. Basic Clin. Pharmacol. Toxicol. 97(5), 261-275 (2005)

19. Archibugi, D., Coco, A.: A new indicator of technological capabilities for developed and developing countries (ArCo). World Dev. 32(4), 629-654 (2004)

20. Ernst, H., Omland, N.: The Patent Asset Index-A new approach to benchmark patent portfolios. World Pat. Inf. 33(1), 34-41 (2011)

21. Korea Institute of Science and Technology Evaluation and Planning (KISTEP): Report on Science and technology level evaluation in 2010 (2012)

22. Korea Evaluation Institute of Industrial Technology (KEIT): Survey report on total industrial technology level in 2011 (2011)

23. Defense Agency for Technology and Quality (DTaQ): Survey Report on Defense Technology Level in 2012 (2012)

24. Ernst, H.: Patent information for strategic technology management. World Pat. Inf. 25(3), 233-242 (2003)

25. Griliches, Z.: Patent statistics as economic indicators: a survey. In: Zvi Griliches (eds.) R\&D and Productivity: The Econometric Evidence, pp. 287-343. University of Chicago Press, Chicago (1998)

26. Fai, F.M.: Using intellectual property data to analyze China's growing technological capabilities. World Pat. Inf. 27(1), 49-61 (2005)

27. Thomas, V.J., Sharma, S., Jain, S.K.: Using patents and publications to assess R\&D efficiency in the states of the USA. World Pat. Inf. 33(1), 4-10 (2011)

28. Archibugi, D., Planta, M.: Measuring technological change through patents and innovation surveys. Technovation 16(9), 451-519 (1996)

29. Ernst, H.: Patent applications and subsequent changes of performance: evidence from time-series cross-section analyses on the firm level. Res. Policy 30(1), 143-157 (2001)

30. Tseng, F.M., Hsieh, C.H., Peng, Y.N., Chu, Y.W.: Using patent data to analyze trends and the technological strategies of the amorphous silicon thin-film solar cell industry. Technol. Forecast. Soc. 78(2), 332-345 (2011) 
31. Heng, T.: The empirical analysis of enterprise scientific and technological innovation capability. Energy Procedia 5, 1258-1263 (2011)

32. Satty, T.L.: The Analytic Hierarchy Process: Planning, Priority Setting, Resource Allocation. McGraw, New York (1980)

33. Zimmermann, H.J.: Fuzzy Sets, Decision Making and Expert Systems, vol. 10. Springer, New York (1987)

34. Graham, I., Jones, P.L.: Expert Systems: Knowledge, Uncertainty, and Decision. Chapman \& Hall, London (1988)

35. Yeh, C.H., Willis, R.J., Deng, H., Pan, H.: Task oriented weighting in multi-criteria analysis. Eur. J. Oper. Res. 119(1), 130-146 (1999)

36. ITU Internet Reports: The Internet for a Mobile Generation. ITU, Geneva (2002)

37. Henten A., Olesen H., Saugstrup D., Tan S.E. (2004) Mobile communications: Europe, Japan, and South Korea in a comparative perspective. Info 6(3):197-207

38. Nagy, M., Singh, S.: Multicast scheduling algorithms in mobile networks. Clust. Comput. 1, 177-185 (1998)

39. Ueno, H., Ishikawa, N., Suzuki, H., Sumino, H., Takahashi, O.: Performance evaluation of WAP and internet protocols over WCDMA networks. Clust. Comput. 8, 27-34 (2005)

40. Jang, K., Han, M., Cho, S., Ryu, H.K., Lee, J., Lee, Y., Moon, S.B.: $3 \mathrm{G}$ and $3.5 \mathrm{G}$ wireless network performance measured from moving cars and high-speed trains. In: Proceedings of the 1st ACM workshop on mobile internet through cellular networks, pp. 19-24. ACM, New York (2009)

41. Madden, G., Morey, A., Bohlin, E.: A global analysis of third generation mobile telecommunications market entry. 22nd European Regional ITS Conference, Budapest 2011: Innovative ICT Applications-Emerging Regulatory, Economic and Policy Issues 52155, International Telecommunications Society (ITS) http://econstor.eu/bitstream/10419/52155/1/672542137.pdf (2011). Accessed October 152013

42. Anastasi, G., Borgia, E., Conti, M., Gregori, E.: IEEE 802.11b Ad hoc networks: performance measurements. Clust. Comput. 8, 135-145 (2005)

43. Dahlman, E., Parkvall, S., Skold, J.: 4G: LTE/LTE-Advanced for Mobile Broadband: LTE/LTE-Advanced for Mobile Broadband. Academic Press, London (2011)

44. Akyildiz, I.F., Gutierrez-Estevez, D.M., Reyes, E.C.: The evolution to 4G cellular systems: LTE-Advanced. Phys. Commun. 3(4), 217244 (2010)

45. Vinkler, P.: An attempt of surveying and classifying bibliometric indicators for scientometric purposes. Scientometrics 13(5-6), 239-259 (1988)

46. Busic, A., Fourneau, J.M.: Monotonicity and performance evaluation: applications to high speed and mobile networks. Clust. Comput. 15, 401-414 (2012)

47. Huang, M.H., Chen, D.Z., Chang, H.W.: National science and technology competitiveness: an aspect from Patentometrics. Bull. Libr. Assoc. China 70, 18-30 (2003)

48. Chen, Y.S., Chang, K.C.: The relationship between a firm's patent quality and its market value - the case of US pharmaceutical industry. Technol. Forecast. Soc. Change 77(1), 20-33 (2010)

49. Traijtenberg, M.: A penny for your quotes: patent citations and the value of innovation. RAND J. Econ. 21(1), 172-187 (1990)

50. Breitzman, A., Thomas, P.: Using patent citation analysis to target/value ma candidates. Res. Technol. Manag. 45(5), 28-36 (2002)
51. Harhoff, D., Scherer, F.M., Vopel, K.: Citations, family size, opposition and the value of patent rights. Res. Policy 32(8), 1343-1363 (2003)

52. Narin, F.: Patents as indicators for the evaluation of industrial research output. Scientometrics 34(3), 489-496 (1995)

53. Chia, K.C.: Measuring the Patent Effectiveness in Biotechnology Industry. National Central University, Tao-Yuan (2004)

54. Guellec, D.,van Pottelsberghe de la Potterie, B.: Applications, grants and the value of patent. Econ. Lett. 69(1), 109-114 (2000)

55. Schmoch, U.: Tracing the knowledge transfer from science to technology as reflected in patent indicators. Scientometrics 26(1), 193211 (1993)

56. Expert Choice: The Expert Choice register. http://expertchoice. com (2012). Accessed 9 November 2012

57. Lee, D., Lee, H., Park, D., Jeong, Y.S.: Proxy based seamless connection management method in mobile cloud computing. Clust. Comput. 16, 1-12 (2013)

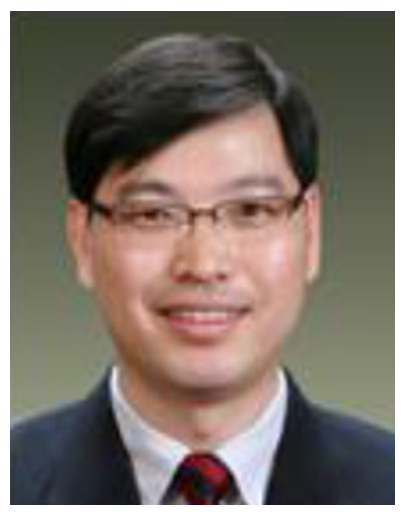

Ilgu Cho is a doctoral candidate in the Department of Business and Technology Management at Korea Advanced Institute of Science and Technology (KAIST). He received B.S. degree in Applied Statistics in Chung-Ang University and M.S. degree in Computer Science and Statistics in Seoul National University, Seoul, Korea (respectively in 1994 and 1996). He has been working at Korea Evaluation Institute of Industrial Technology since 2000. His research interests include technology forecasting, evaluation, and R\&D project planning in ICT industry.

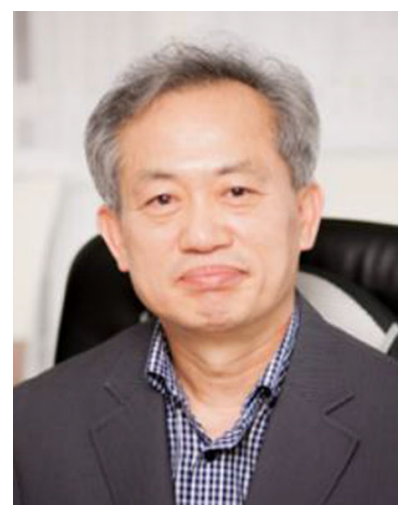

Myeongcheol Park is a professor and chair in the Department of Business and Technology Management at Korea Advanced Institute of Science and Technology (KAIST). He received B.S. degree in Industrial Engineering, M.A. degree in Business in Seoul National University, and Ph.D. degree in Business in The University of Iowa, USA (respectively 1976, 1982, and 1990). His research interests include telecommunications management strategy and economics, demand forecasting and market analysis, interconnection, information technology management, and e-business management. 